\section{Effect of Depreciation of the Exchange Rate on the Trade Balance of Albania}

\author{
Safet Kurtović \\ University of Travnik, Faculty of Management and Business Economics, \\ Bosnia and Herzegovina \\ safetkurtovic71@yahoo.com
}

Blerim Halili

College “Biznesi”, Department of Economics, R. Kosovo

blerimhalili547@yahoo.com

\section{Nehat Maxhuni}

College “Biznesi”, Department of Economics, R. Kosovo

nehati504@yahoo.com

\begin{abstract}
The paper investigates the effect of the real effective exchange rate depreciation of the lek on the trade balance of Albania using quarterly data from 1994 to 2015. Bounds testing cointegration approach, vector error correction model (VECM), and impulse response were used for the empirical analysis. The results of the study show a long-term cointegration between the real effective exchange rate (REER) and the trade balance (TB). Specifically, the REER depreciation positively affects the trade balance of Albania in both the long and short run, indicating the weak presence of the J-curve effect. Important recommendations were derived from the results.
\end{abstract}

Keywords: J-curve, cointegration, elasticity, short-term effect, long-term effect

\section{Introduction}

There is a strong argument among international trade economists that depreciation causes a decrease in the trade balance deficit (Bahmani-Oskooee, 1985). The real exchange rate is an important macroeconomic measure underlying the adoption of certain economic policies. It indirectly affects the allocation of resources in the economy, i.e., traded and non-traded goods. An overvalued exchange rate is interpreted as a reduction or a decline in price competitiveness, while an undervalued exchange rate is interpreted as a way toward faster economic growth (Rodrik, 2008; Cakrani et al., 2013). Real exchange rate depreciation leads in the short term to deterioration in the trade balance, while in the long term it leads to balance (Šimakova, 2013; Šimakova \& Stavarek, 2015). Trade balance represents a relationship between the volume of exports and imports. In the case of imports being higher than exports, we have a deficit, and vice versa, we have a surplus (Krueger, 1983). Trade balance can be improved in two ways. The first is through an internal approach, which is based on supply-side policies that improve
ORIGINAL SCIENTIFIC PAPER

RECEIVED: FEBRUARY 2017

REVISED: JULY 2017

ACCEPTED: JULY 2017

DOI: 10.1515/ngoe-2017-0016

UDK: 339.5

JEL: F14, F31, F32

Citation: Kurtović, S., Halili, B., \& Maxhuni, N. (2017). Effect of Depreciation of the Exchange Rate on the Trade Balance of Albania. Naše gospodarstvo/Our Economy, 63(3), 27-36. DOI: 10.1515/ngoe-2017-0016

\section{NG OE}

NAŠE GOSPODARSTVO OUR ECONOMY

\section{Vol.63 No.3 2017}

pp. 27-36 
productivity, reduce inflation and taxes, and lead to a more efficient labor market. In the end, these measures lead to the growth of GDP and exports. Another way is currency depreciation, which leads to changes in relative prices of imports and exports (Krueger, 1983; Stučka, 2004; Kurtovic et al., 2016).

The economic concepts of J-curve and devaluation of exchange rate are closely related. Magee (1973) was the first to introduce the concept of J-curve. Real exchange rate devaluation in the short term worsens the trade balance because the volume of imports remains stable but more expensive due to a lower exchange rate. In the long run, there is an increase in exports and reduction in imports, leading to improved trade but not enough to achieve a surplus. The effect of depreciation leads to a decline in the prices of exports relative to imports (Khieu Van, 2013; Nagpal, in press; Sahlan et al., 2008; Kurtovic et al., 2016). Such a condition causes the trade balance to have a movement in the form of a slanted J-curve (Magee, 1973; Bahmani-Oskooee \& Kantipong, 2001; Bahmani-Oskooee \& Goswami, 2003; Harvey, 2013; Kurtovic et al., 2016). After depreciation, there is the effect of a time lag in the trade balance. The time lag is a result of the slow recognition of resulting changes, making the right decisions, delivery delays, procurement of raw materials and the cost-effectiveness of continuing the process of production (Junz et al., 1973; Krugman \& Baldwin, 1987; Bahmani-Oskooee, 1985; Kurtovic et al., 2016).

After the fall of the communist regime in 1990, Albania had begun the process of democratization and transition (Cera et al., 2013). Until 1992, Albania had a fixed exchange rate, which, due to the poor state of the economy, was no longer viable. In late 1992, Albania introduced a floating exchange rate regime. The flexible or floating rate influenced the strong devaluation of the lek and the emergence of inflation, which had a negative impact on the growth of the prices as a result of higher imports in relation to the volume of the GDP (Agolli, 2004; Kola \& Likko, 2008). As in other countries in southeast Europe, Albania recorded a negative trade balance in the period from 1994 to 2015 (see Figure 1). The crucial question is: What are the major causes of trade balance deterioration in a country?

The main objectives of this work are: 1) to investigate potential presence of cointegration variables; 2) to investigate whether there is a short-term effect and longterm effect of the real depreciation of the ALL on the trade

Figure 1. Display Variables Used in the Analysis

TB
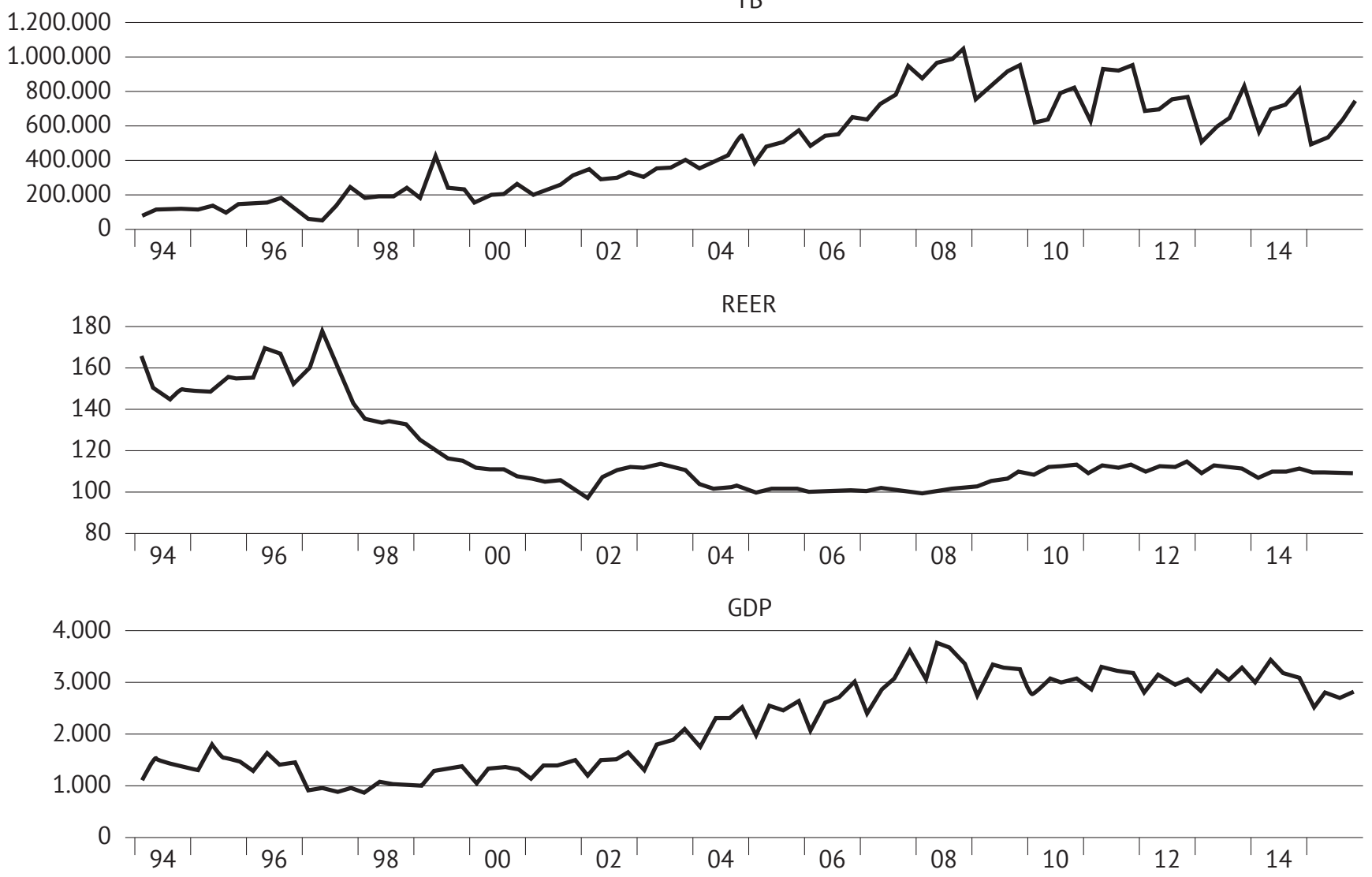

Source: Author's compilation using data from the Bank of Albania, World Bank (WDI), and International Financial Statistics (IMF database). 
balance of Albania or whether there is the presence effect of the J-curve.

To achieve these objectives, the remaining sections are arranged as follows: Section 2 reviews the related literature, Section 3 contains databases used in the research and economic analysis, Section 4 presents the research results, and Section 5 gives the conclusion.

\section{Literature Review}

It is well known that numerous studies are attempting to confirm the presence of the J-curve, based on the traditional approach. The existence of the J-curve is confirmed by the following research of authors such as Spitaller (1980), Bahmani-Oskooee (1985), Krugman and Baldwin (1987), Demirden and Pastine (1995), Marwah and Klein (1996), Bahmani-Oskooee and Brooks (1999), Bahmani-Oskooee and Kantipong (2001), Willson (2001), Hacker and Hatemi-J (2003), Stučka (2004), Bahmani-Oskooee and Kutan (2006), Bahmani-Oskooee and Ratha (2007), Hsing (2008), Kalyoncu et al. (2009), Petrović i Gligorić (2010), Šimakova (2013; 2014). On the other hand, a slight or no presence of the J-curve was found by authors such as Flemingham (1988), Rose and Yellen (1989), Demeulemeester and Rochat (1995), Bahmani-Oskooee and Goswami (2003), Yuen-Ling and Wai-Mun (2008).

Hacker and Hatem-J (2003) investigated the presence of the J-curve in the example of north European economies. The study used econometric techniques, Johansen and Juselius maximum likelihood approach, and vector error correction methods. The results showed the presence of the J-curve or a positive effect of real depreciation on the trade balance of the analyzed countries. Stučka (2004) investigated the effect of the depreciation of exchange rate on the trade balance of Croatia. The study used quarterly data from 1994 to 2001 and applied the cointegration approach. The results showed the presence of the J-curve phenomenon. Bahmani-Oskooee and Kutan (2006) investigated the effect of depreciation on the trade balance of 11 countries in central and eastern Europe. The study used quarterly data from 1990 to 2005, and then applied cointegration approach and errorcorrection modeling. The results showed the presence of the J-curve in the cases of Russia, Croatia, and Bulgaria. Vika (2006) investigated the response of exports and imports to the change of income, relative prices, and exchange rate in Albania in the period from 1996 to 2005. The study used quarterly data and applied the vector error correction. The results showed that real income has a dominant influence on trade flows, particularly on exports in the long term, while changes in prices have a greater impact on imports than the currency exchange rate. In addition, the study investigated the presence of M-L conditions and whether depreciation has a positive effect on reducing the trade deficit of Albania.

Petrović and Gligorić (2010) investigated the presence of the J-curve or the effect of depreciation on trade balance of Serbia. The study applied the ARDL model and Johansen's approach analysis. The results showed the presence of the J-curve. Hoda (2013) investigated the effect of depreciation of exchange rates on the trade balance of Albania. The study used quarterly data from 1998 to 2012 and applied the model of imperfect substitution and the Johansen's approach. The results showed that income has a particular impact on trade flows, while the effect of exchange rate is present in exports and has a significant impact on reducing the trade deficit. Šimakova (2013) investigated the effect of depreciation on the trade balance of Hungary with major trading partners. The study applied the Johansen cointegration test and used the quarterly data from 1997 to 2012. The results showed the presence of the J-curve in the case of the bilateral trade with the United Kingdom. Šimakova (2014) investigated the effect of depreciation on the trade balance of Slovakia in the process of the bilateral trade with Poland, the Czech Republic, and Hungary. The study used aggregate and disaggregate quarterly data from 1997 to 2013. In addition, the study applied the cointegration approach. The results showed the presence of the J-curve in the cases of Hungary and the Czech Republic.

\section{Data and Methodology}

The interpolated (no-seasonally adjusted) quarterly data 1994-2015 was used in this study to estimate the effect of real depreciation of the real effective exchange rate (REER) on the trade balance of Albania. Data were taken from the Instat - Bank of Albania, World Bank (WDI), International Financial Statistics (IMF database) and Eurostat. Appendix to this research contains data resources and description of variables.

This study uses the standard model, based on the model of imperfect substitution "two country," developed by Goldstein and Khan (1976) and Rose and Yellen (1989). The model of imperfect competition assumes that two countries are in partial equilibrium with imperfect substitution, where import and domestic products are imperfectly substituted. In fact, the model is based on the following assumptions; first, one country is either an importer, and the other an exporter or vice versa - but not both simultaneousley. Second, there are different prices of the same products in both countries, indicating that the law of one price does not apply (Cheng, 2009): 
$T B=T B\left(Q, Y, Y^{f}\right)$,

where $T B$ is the trade balance between the domestic country and its trading partners; $Q$ is the real exchange rate; $Y$ the real incomes of the domestic country; $Y^{f}$ the real incomes of the trading partners.

Equation (1) is the basic equation for the analysis and can be written if as in log-linear form (Hameed \& Kanwal, 2009):

$$
\begin{aligned}
\ln T B_{t}= & \beta_{0}+\beta_{1} \ln R E E R_{t}+\beta_{2} \ln G D P_{i, t} \\
& +\beta_{3} \ln G D P_{j, t}+e_{t},
\end{aligned}
$$

where $\ln T B_{t}$ represents the trade balance between the domestic country and its trading partners in time $t ; \ln R E E R_{t}$ represent the real effective exchange rate at time $t ; \ln G D P_{i, t}$ represent the real incomes of the domestic country $i$ at time $t$; $\ln G D P_{j, t}$ represent the real income of the trading partners $j$ at time $t$; $\ln$ represent the natural logarithm; $\beta_{0}, \beta_{1}, \beta_{2,} \beta_{3}$ represent the parameters; $e_{t}$ represent the error term.

Upon preliminary testing, it turns out that foreign income is not significant statistically. In this light, the model to be estimated becomes

$$
\operatorname{lnTB} B_{t}=\beta_{0}+\beta_{1} \ln R E E R_{t}+\beta_{2} \ln G D P_{i, t}+e_{t} .
$$

The research is based on the application of the cointegration approach, better known as the autoregressive distributed lag (ARDL). It is cointegration modelling, which is widely accepted by researchers. The ARDL model was developed by Pesaran and Shin (1999) and Pesaran et al., (2001). The ARDL model has the following characteristics: the model is statistically more efficient in the process of determining cointegration relationships in small samples; the model can be applied when the regressors are not of the same order or when the regressors are I(1) and/or I(0), i.e., it is not necessary to perform pre-testing for the existence of problems of the standard deviation; it is not necessary to operate a unit root test in the model, which means that it can be applied regardless of the fact of whether the regressors in the model are stationary, nonstationary, or mutually cointegrated (Pessaran et al., 2001; Pahlavani, et al. 2005; Ketenci \& Uz, 2011).

The ARDL model requires the following two steps (Pesaran et al., 2001). The first step relates to the process of determining any significant long-term relationship between the variables using the F-test. The second step relates to the long-term relationship variables and determining their value, along with assessment of the short-term elasticity of variables showing the error correction representation of the ARDL model. The result of the error correction model tells us about the speed of adjustment from the short-term shock to the long-term balance (Siddiqui et al., 2008; Kurtovic et al., 2016). The ARDL model is represented by the following equations:

$$
\begin{aligned}
\Delta \ln T B_{t}= & \beta_{0}+\beta_{1} t+\beta_{2} \Delta x_{t}+ \\
& +\sum_{\mathrm{i}=1}^{m} \alpha_{1 i} \Delta \ln \Delta T B_{t-1}+ \\
& +\sum_{\mathrm{i}=0}^{m} \alpha_{2 i} \Delta \ln R E E R_{t-1}+ \\
& +\sum_{\mathrm{i}=0}^{m} \alpha_{3 i} \Delta \ln G D P A l b_{t-1}+\lambda_{1} T B_{t-1}+ \\
& +\lambda_{2} R E E R_{t-1}+\lambda_{3} \text { GDPAlb }_{t-1}+e_{t}
\end{aligned}
$$

where $\Delta \ln T B_{t}, \Delta \ln \Delta T B_{t-1}$ represent the first difference of the trade balance between the domestic country and its trading partners at time $t$ and $t-1 ; \Delta \ln R E E R_{t-1}$ represents the first difference of the real effective exchange rate at time $t-1 ; \Delta \ln G D P A l b_{t-1}$ represents the first difference of the real incomes of the domestic country $i$ at time $t-1 ; \beta_{1} t$ and $\beta_{2} \Delta x_{t}$ represent the trend; $\alpha_{2}$ and $\alpha_{3}$ represent the shortterm effect of the exchange rate and the domestic income on the trade balance; $\lambda_{2}$ and $\lambda_{3}$ represent the long-term effect of real depreciation of the exchange rate and the effect of income on the trade balance; $m$ represents the number of lags; $\beta_{0}, \beta_{1}, \beta_{2}, \beta_{3}$ represent drifts; In represents the natural logarithm; $e_{t}$ represents the error term.

In Equation (4), we expect $\alpha_{2}$ and $\lambda_{2}$ to have a negative sign. The real depreciation of the domestic currency leads to a reduction in imports, thus improving the trade balance. We also expect $\alpha_{3}$ and $\lambda_{3}$ to have a positive or negative sign. A decrease in the domestic income will lead to a decrease in imports from abroad; on the other hand, an increase in the domestic income will lead to an increase in exports as well as imports of raw materials and intermediate goods owing to the increased volume of the domestic production.

The steps in the bounds process are based on the F- or Wald statistics and represent the first phase of ARDL cointegration method. The second phase relates to the F-test of the null hypothesis of long-term variables with a time lag whose aggregate value equals zero, while in the case of the alternative hypothesis at least one long-term variable does not equal zero. This relationship is represented by the following relation (Bernstein \& Madlener, 2011; Kurtovic et al., 2016):

Null Hypothesis or $H_{0}: \alpha_{1}=\alpha_{2}=\alpha_{3}=0$ and

$H_{0}{ }^{\prime}: \lambda_{1}=\lambda_{2}=\lambda_{3}$, i.e., the long-run relationship does not exist.

Alternative Hypothesis or $H_{1}: \alpha_{1} \neq \alpha_{2} \neq \alpha_{3} \neq 0$ and

$H_{1}^{\prime}: \lambda_{1} \neq \lambda_{2} \neq \lambda_{3}$, i.e., the long-run relationship exists. 
Pesaran et al., (2001) calculated two levels of the critical value for the given level of significance. One level assumes that all variables are $\mathrm{I}(0)$, and the second level assumes that all the variables are I(1). In order to perform the specified testing, we will use the OLS model (3) with or without the linear trend and with and without $\Delta x_{t}$ (first difference of current exogenous variables). The length of lags is chosen based on the Akaike Information Criterion (AIC) and Schwarz Bayesian Criterion (SBC) (Halicioglu, 2005; Petrović \& Gligorić, 2010; Kurtovic et al., 2016).

Finally, we will apply the impulse response function based on the calculated ECM, which allows the subsequent assessment of the trade balance for a certain period, i.e., the effect of real depreciation (Petrović \& Gligorić, 2010). The impulse response function is defined as (Nguyen, 2011; Kurtovic et al., 2015):

$I R\left(m, h, Z_{t-1}\right)=E\left(\frac{y_{t+m}}{e_{t}}=h, Z_{t-1}\right)-E\left(\frac{y_{t+m}}{Z_{t-1}}\right)$,

where $m$ denotes time, $h=\left(h_{1}, \ldots, h_{m}\right)$ is $n x 1$ vector that denotes the size of a shock, $Z_{t-1}$ denotes the accumulative information about economy from the past up to time $t-1$.

\section{Empirical Results}

Table 1 presents the results of the F-test or the Bond test. Based on the application of the F-test, we got the same number of lags for all variables, i.e. from 1 to 8 . The optimal number of lags is obtained based on the AIC or the SBC. For the relation $\beta_{1}=0$ and $\beta_{1} \neq 1$ the optimal number of lags is $m=6$. The value of the $\mathrm{F}$ statistics for 6 lags is 14.36 which is greater than the $1 \%$ value of the bound test 3.61, i.e. we can reject the null hypothesis and say there is $\beta_{1} \neq 0$ at the level of $1 \%$ of statistical significance. Identical results were obtained in the cases of relations $\beta_{1} \neq 0$ and $\beta_{2}=0$, i.e. the optimal number of lags is at the level $m=1$ and $m=6$, and the F value is 11.21 and 8.33, which is greater than $1 \%$ of value of the bound test 4.33 . On the basis of the given parameters we reject the null hypothesis and accept the alternative hypothesis that there is $\beta_{1} \neq 0$ at the level of $1 \%$ of statistical significance. For the relations $\beta_{1}=0$ and $\beta_{2} \neq 0$ and $\beta_{1} \neq 0$ and $\beta_{2} \neq 0$ the optimal number of lags is at the second and sixth level. In all cases, the F statistics is greater than the bond statistics which confirms the presence of cointegration. In the end, the values of the coefficients show that there is no trend.
Table 1. Results of the F-test

\begin{tabular}{|c|c|c|c|c|c|c|}
\hline \multirow{3}{*}{$\begin{array}{l}m- \\
\text { lag length }\end{array}$} & \multicolumn{3}{|c|}{$\beta_{1}=0$} & \multicolumn{3}{|c|}{$\beta_{1} \neq 0$} \\
\hline & \multicolumn{6}{|c|}{$\beta_{2}=0$} \\
\hline & AIC & SC & F-stat & AIC & SC & F-stat \\
\hline 1 & -0.93 & -1.13 & 17.1 & -1.40 & -1.54 & 11.2 \\
\hline 2 & -0.98 & -1.23 & 16.9 & -1.39 & -1.59 & 4.94 \\
\hline 3 & -1.01 & -1.32 & 15.6 & -1.34 & -160 & 6.73 \\
\hline 4 & -1.04 & -1.41 & 15.8 & -1.38 & -1.70 & 6.74 \\
\hline 5 & -1.06 & -1.50 & 14.6 & -1.33 & -1.71 & 8.25 \\
\hline 6 & -1.10 & -1.60 & 14.3 & -1.37 & -1.81 & 8.33 \\
\hline 7 & -0.72 & -1.28 & 12.6 & -1.12 & -1.62 & 11.4 \\
\hline \multirow[t]{2}{*}{8} & -0.74 & -1.37 & 16.6 & -1.15 & -1.71 & 6.91 \\
\hline & \multicolumn{6}{|c|}{$\beta_{2} \neq 0$} \\
\hline 1 & -1.10 & -1.30 & 8.20 & -1.11 & -1.28 & 14.9 \\
\hline 2 & -1.15 & -1.40 & 5.66 & -1.17 & -1.39 & 13.5 \\
\hline 3 & -1.15 & -1.47 & 5.37 & -1.14 & -1.42 & 14.5 \\
\hline 4 & -1.18 & -1.55 & 5.68 & -1.17 & -1.51 & 14.9 \\
\hline 5 & -1.18 & -1.61 & 5.79 & -1.16 & -1.57 & 14.9 \\
\hline 6 & -1.20 & -1.70 & 6.39 & -1.18 & -1.65 & 15.5 \\
\hline 7 & -0.79 & -1.35 & 11.1 & -0.76 & -1.29 & 14.0 \\
\hline 8 & -0.83 & -1.45 & 9.44 & -0.80 & -1.40 & 18.8 \\
\hline
\end{tabular}

Notes: The relevant critical value bounds for F-statistics are taken from tables CI. iii case III in Pesaran et al. (2001). Unrestricted intercept and no trend (2.45-3.61) at $0.5 \%$ significance level, (3.15-4.33) at $0.1 \%$ significance level.

Source: Author's compilation

After we investigated the presence of cointegration, our research is further directed towards the assessment of cointegration vectors. For the calculation of the cointegration vector, we again use model (4), on the basis of which we estimate the optimal number of lags for each variable ARDL model $(1,6,6)$ - represented in Table 2. The assessed ARDL $(1,6,6)$ model in Table 2 gives the following cointegration coefficients (with $t$ - coefficient in parenthesis): $\lambda_{1}=-0.47(-3.48), \lambda_{2}=-1.98(-5.19), \lambda_{3}=0.76(5.00)$. Then we got the long-term equation of trade balance by renormalization of the obtained cointegration vector, i.e. dividing by $\lambda_{1}$.

Theoretically, if you have $x$ variables you can have $x-1$ cointegrating vectors. It does not have to be so, however: it's perfectly all right if you find that variables are connected via a single cointegrating relationship. The cointegrating vectors describing a rule (equilibrium relationship) that bind a group of variables together. We found that variables are connected via a single cointegrating relationship or equilibrium relationship of long-term equation of trade balance.

$\Delta \operatorname{lnT} B_{t}=16.3-4.3 \Delta \ln R E E R_{t-1}+0.7 \Delta \ln G D P A l b_{t-1}$ 
Table 2. ARDL $(1,6,6)$ - long-term cointegration

\begin{tabular}{lcc} 
Variable & Coefficients & t-stat \\
\hline$T B_{t-1}$ & -0.47 & -3.48 \\
\hline$R E E R_{t-1}$ & -1.98 & -5.19 \\
\hline GDPAlb $_{t-1}$ & 0.76 & 5.00 \\
\hline$\Delta l n R E E R_{t-1}$ & -2.31 & -6.08 \\
\hline$\Delta l n R E E R_{t-2}$ & -2.30 & -5.60 \\
\hline$\Delta \ln R E E R_{t-3}$ & -2.18 & -5.50 \\
\hline$\Delta l n R E E R_{t-4}$ & -2.11 & -5.32 \\
\hline$\Delta l n R E E R_{t-5}$ & -2.03 & -5.16 \\
\hline$R^{2}$ & & \\
\hline Adj $R^{2}$ & & \\
\hline Log likelihood & & \\
\hline S.D. dependent var & 0.64 & \\
\hline Durbin-Watson stat & 1.86 & \\
\hline Akaike infor. criterion & 1.18 & \\
\hline Schwarz criterion & 1.65 & \\
\hline
\end{tabular}

Source: Author's compilation

Based on the resulting co-integration equation, ARDL $(1,6,6)$ model shows the positive impact of real depreciation and income on the trade balance. Long-term real depreciation leads to an improvement of the trade balance, while, on the other hand, long-term appreciation leads to a deterioration in the trade balance. The estimated or calculated elasticity is $4.3 \%$, which indicates that the real depreciation of $1 \%$ causes an improvement of $4.3 \%$ in the trade balance. In addition, based on the equation of trade balance, the growth of domestic income or the $G D P_{i, t}$ leads to an improvement of the trade balance. The estimated elasticity of $G D P_{i, t}$ is $0.7 \%$. These results suggest that a $1 \%$ increase in domestic income or $G D P_{i, t}$ would account for a $0.7 \%$ increase in Albanian trade balance. The growth of domestic income occurred as a result of the growth in domestic production and exports, i.e. the growth of foreign demand. Namely, research studies Rincón (1999), Petrović and Gligorić (2010), Vika (2006) have confirmed our results that the real depreciation and income growth have a positive effect on trade balance. The GDP growth of Albania from 1997 to 1999 experienced the largest decline as a result of political unrest that occurred then, to grow in the coming years, or more precisely to 2008. After 2008, the GDP significantly fell as a result of the global economic crisis and post-crisis cyclical years.

Table 3 presents the results of coefficients based on the introduction of error correction model (the coefficients of $E C_{(t-1)}$ of the error-correction model). ECM model serves to show the short-term effect of real depreciation of exchange rate on the trade balance.
Table 3. ECM for trade balance on ARDL $(1,6,6)$ model - shortterm effect

\begin{tabular}{|c|c|c|c|}
\hline Variable & & Coefficients & t-stat \\
\hline$\triangle R E E R_{t-1}$ & & -0.66 & -0.49 \\
\hline$\triangle R E E R_{t-2}$ & & 2.06 & 1.79 \\
\hline$\triangle R E E R_{t-3}$ & & 2.36 & 2.04 \\
\hline$\triangle R E E R_{t-4}$ & & 2.98 & 2.25 \\
\hline$\triangle R E E R_{t-5}$ & & 4.50 & 3.69 \\
\hline$\triangle R E E R_{t-5}$ & & 2.36 & 1.96 \\
\hline$E C_{(t-1)}$ & & -0.33 & -2.99 \\
\hline$R^{2}$ & 0.67 & & \\
\hline $\operatorname{Adj} R^{2}$ & 0.59 & & \\
\hline Log likelihood & -28.7 & & \\
\hline S.D. dependent var & 0.61 & & \\
\hline Durbin-Watson stat & 2.02 & & \\
\hline Akaike infor. criterion & 1.10 & & \\
\hline Schwarz criterion & 1.57 & & \\
\hline LM & 0.94 & & \\
\hline RESET & 0.76 & & \\
\hline Normality & 0.28 & & \\
\hline CUSUM & stable & & \\
\hline CUSUM of squares test & stable & & \\
\hline
\end{tabular}

Source: Author's compilation

$E C_{(t-1)}$ is obtained on the basis of equation (4) and the results of the coefficients are represented in Table 3. Based on the values of the coefficients, a weak effect of the J-curve has been observed, which assumes that the coefficients of exchange rate are negatively significant in shorter time lags, and positively significant in longer time lags.

Research studies Flemingham (1988), Rose and Yellen (1989), Demeulemeester and Rochat (1995), BahmaniOskooee and Goswami (2003), Yuen-Ling and Wai-Mun (2008) have also confimred the presence of the J-curve, however to a greater extent compared to our result. Thus, in the first quarter we have a negative value of -0.66 , while in other quarters the value is positive. The calculated value $E C_{(t-1)}$ for $R E E R$ is negatively significant, i.e. the value of the coefficient is -0.33 and the t-statistics -2.99 . The negative value $E C_{(t-1)}$ shows a direct deterioration of the trade balance after depreciation, whereas the effect of appreciation has a reverse effect. $E C_{(t-1)}$ tells us about the speed of the equilibrium adjustment which is $42 \%$, which means that the imbalance of the trade balance is corrected in less than a year. In the short-run real depreciation affects the deterioration of the trade balance, while in the long-run it affects the improvement of the trade balance. 
In addition, Table 3 presents the diagnostic statistics. Adj $R^{2}$ has an optimum value in all tested cases. LM test tells us that there is no autocorrelation in the disturbance of the error term. Jarque-Bera normality test shows us that the model errors are normally distributed. Heteroscedasticity tests are significant at the $5 \%$ level in all cases. The RESET test tells us that the models are correctly specified. In the cases of CUSUM and CUSUMSQ tests, the stability of our model is confirmed.

The impulse response function is obtained on the basis of $E C_{(t-1)}$ and provides the ability to assess the evolution of the trade balance subsequently after real depreciation. The results are presented in Figure 2, and show that the trade balance worsened in the first ten quarters after real depreciation, and that it only improved and reached a new equilibrium value in the $11^{\text {th }}$ quarter. The results of the impulse response show a weak presence effect of the J-curve in the relationship between the depreciation of the real effective exchange rate and the trade balance of Albania.

Finally, we want to emphasize that the scientific contribution of our research is reflected in the following. In the first place, we explored the presence of the short and the long- term effect of real depreciation of the exchange rate on the trade balance of Albania: the GDP of Albania has a positive effect on the trade balance in the long term, and the real depreciation has a positive effect on the trade balance in the short run, i.e., a weak presence effect of the J-curve. Second, real depreciation has a negative effect on the trade balance worsened in the first quarter to gradually improve in the following quarters, and to achieve balance only in the eleventh quarter.

\section{Conclusion}

The results of this study showed the presence of the shortterm and the long-term effect of real depreciation of the exchange rate on the trade balance of Albania. The results showed that the GDP of Albania has a positive effect on the trade balance in the long term. Namely, research studies Gupta-Kapoor and Ramakrishnan (1999), Rincón (1999), Petrović and Gligorić (2010), Vika (2006) have confirmed our results that the real depreciation and income growth have a positive effect on trade balance. In addition, using vector error-correction model, or ECM, we explored the positive effect of real depreciation on the trade balance in the short-run, i.e. a weak presence effect of the J- curve. ECM model showed that real depreciation has a negative effect on the trade balance in the first quarter, followed

Figure 2. The reaction of the trade balance on the real depreciation

Response to Cholesky One S.D. Innovations \pm 2 S.E.

Response of LTB to LTB

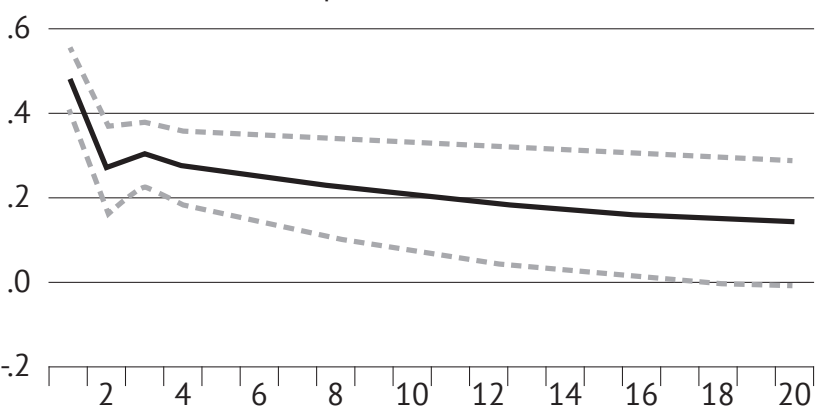

Response of LREER to LTB

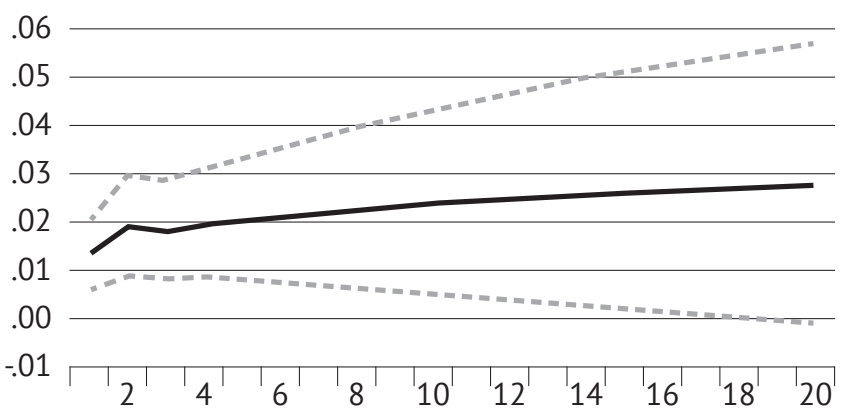

Response of LTB to LREER

.6

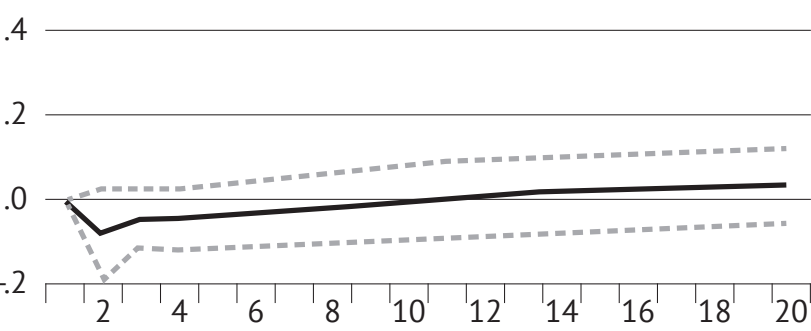

Response of LREER to LREER

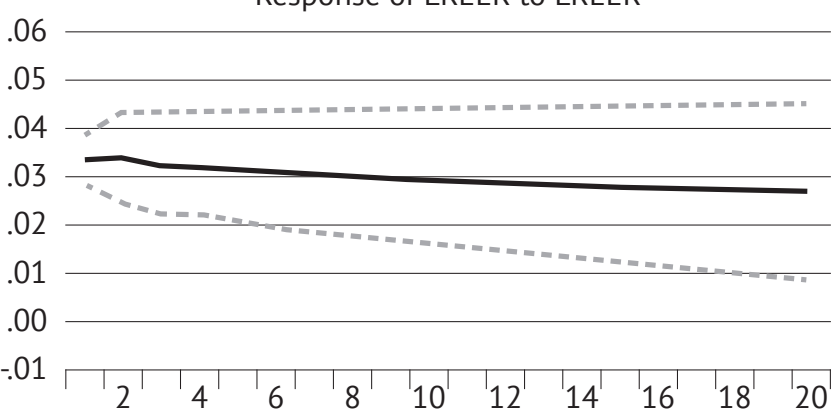

Source: Author's compilation 
by an improvement in the following quarters. Research studies Flemingham (1988), Rose and Yellen (1989), Demeulemeester and Rochat (1995), Bahmani-Oskooee and Goswami (2003), Stučka (2004), Kutan (2007) have also confimred the presence of the J-curve, however to a greater extent compared to our result. Along these lines, we applied the impulse response and the impulse response of the trade balance to the real depreciation. The result showed a weak presence effect of the J-curve, calculated on the basis of $E C_{(t-1)}$ and unrestricted VAR model, i.e. the trade balance worsened in the first quarter to gradually improve in the following quarters, and to achieve balance only in the eleventh quarter. Research studies Noland (1989) and Petrović and Gligorić (2010) have confirmed our results.

It is evident that the real exchange rate depreciation can improve the trade balance in the long run. However, the use of depreciation can't be significantly effective without the use of appropriate macroeconomic policies. When combined, real depreciation and macroeconomic policies can improve the competitiveness of an economy, i.e. export activity.

Acknowledgments: I would like to thank Ilir Vika and reviewers for helpful comments.

\section{References}

Agolli, M. (2004). Exchange rate volatility effect on trade variations. Retrieved from http://pdc.ceu.hu/archive/00002085/01/may_2004_ MAgolli.pdf

Bahmani-Oskooee, M. (1985). Devaluation and the J-curve: Some evidence from LDCs. The Review of Economics and Statistics, 67(3), 500-504. Retrieved from http://dx.doi.org/10.2307/1925980

Bahmani-Oskooee, M., \& Kantipong, T. (2001). Bilateral J-curve between thailand and her trading partners. Journal of Economic Development, 26(2), 107-117.

Bahmani-Oskooee, M., \& Goswami, G. G. (2003). A disaggregated approach to test the J-curve phenomenon: Japan versus her major trading partners. Journal of Economics and Finance, 27(1), 102-113. https://doi.org/10.1007/BF02751593

Bahmani-Oskooee, M., \& Brooks, T. J. (1999). Bilateral J-curve between US and her trading partners. Weltwirtschaftliches Arch 135: 156-165. Retrieved from http://dx.doi.org/10.1007/BF02708163

Bahmani-Oskooee, M., \& Kutan, M. A. (2006). The J-curve in the emerging economies of eastern Europe. EMG Working Paper Series WPEMG-01-2006, 1-23.

Bahmani-Oskooee, M., \& Ratha, A. (2007). The bilateral J-curve: Sweden versus her 17 major trading partners. International Journal of Applied Economics, 4(1), 1-13.

Bernstein, R., \& Madlener, R. (2011). Residential natural gas demand elasticities in OECD countries: An ARDL bounds testing approach. FCN Working Paper No. 15,1-29. https://doi.org/10.2139/ssrn.2078036

Cakrani, E., Resulaj, P., \& Koprencka, L. K. (2013). Government spending and real exchange rate case of Albania. European Journal of Sustainable Development, 2(4), 303-310.

Cera, G., Cera, E., \& Lito, G. (2013). A Garch model approach to calculate the value at risk of Albanian lek exchange rate. European Scientific Journal, 9(25), 250-260.

Demeulemeester, J. L., \& Rochat, D. (1995) An empirical investigation of the relationship between the exchange value of the pound and the UK trade balance. Economia Internazionale, 48(3), 347-357.

Demirden, T., \& Pastine, I. (1995). Flexible exchange rates and the J-curve: An alternative approach. Economics Letters, 48, 373-7. Retrieved from http://dx.doi.org/10.1016/0165-1765(94)00634-E

Flemingham, B. S. (1988). Where is the Australian J-curve? Bulletin of Economic Research, 40(1), 43-56. Retrieved from http://dx.doi. org/10.1111/j.1467-8586.1988.tb00253.x

Cheng, K. M. (2009). Three essays in tourism, trade, and economic growth. PhD Disseratation. Auburn. University. Retrieved from https://etd. auburn.edu/bitstream/handle/10415/1896/Dissertation\%20(Ka\%20Ming\%20Cheng).pdf?sequence=1\&isAllowed=y

Goldstein, M., \& Khan, M. S. (1976). Large versus small price changes and the demand for imports. IMF Staff Papers, 23, $200-225$. Retrieved from http://dx.doi.org/10.2307/3866671

Gupta-Kapoor, A., \& Ramakrishnan, U. (1999). Is there a J-curve? A new estimation for Japan. International Economic Journal, 13(4), $71-79$. https://doi.org/10.1080/10168739900000045

Hacker, R. S., \& Hatemi-J, A. (2003). Is the J-curve effect observable for small north European economies? Open Economies Review, 14(2), 119-135. Doi:10.10237/A:102235782845

Hameed, A., \& Kanwal, S. (2009). Existence of a J-curve: The case of Pakistan. Journal of Economic Cooperation and Development, 30(2), 75-98. Retrieved from http://library.sesrtcic.org/files/article/309.pdf

Halicioglu, F. (2005). The demand for new housing in Turkey: An application of ARDL model," Global Business and Economics Review, 9(1), 62-74. http://dx.doi.org/10.1504/GBER.2007.012509

Harvey, H. (2013). Exchange rate sensitivity in the Philippines: Does the J-curve exist? Asian Journal of Business and Management Sciences, 2(10), 51-61.

Hoda, B. (2013). The role of exchange rates in international trade models: Does the Marshall-Lerner condition hold in Albania? Working Paper, 13(52), 1-53. 
Hsing, Y. (2008). A study of the J-curve for seven selected Latin American countries. Global Economy Journal, 8(4), 1-12. http://dx.doi. org/10.2202/1524-5861.1438

Junz, H., \& Rhomberg, R. R. (1973). Price competitiveness in export trade among industrial countries. American Economic Review, 63,412-418.

Kalyoncu, H., Ozturk, I.,Artan, S., \& Kalyoncu, K. (2009). Devaluation and trade balance in Latin American countries. Zbornik radova Ekonomskog fakulteta Rijeka, 27(1), 115-128. Retrieved from https://www.efri.uniri.hr/sites/efri.hr/files/cr-collections/2/ozturk-2009-1.pdf

Ketenci, N., \& Uz U. (2011). Bilateral and regional trade elasticities of the EU.Empirical Economics, 40, 839-854. http://dx.doi.org/10.1007/ s00181-010-0365-8

Khieu Van, H. (2013). The effects of the real exchange rate on the trade balance: Is there a J-curve for Vietnam? A VAR approach. MPRA Paper No. 54490, 1020-1034.

Kola, T., \& Likko, E. (2008). An empirical assessment of alternative exchange rate regimes in medium term in Albania. BERG Working paper series on government and growth No. 58,1-16.

Krueger, O. A. (1983). Exchange rate determination. Cambridge: Cambridge University Press.

Krugman, P., \& Baldwin, E. R. (1987). The persistence of the US trade deficit. Brookings Papers on Economic Activity, 1-21-43. http://dx.doi. org/10.2307/2534513

Kurtovic, S., Talovic, S., \& Dacic, L. (2015). Foreign direct investment and net wages: The case of western Balkan countries. British Journal of Economics, Finance and Management Sciences, 10(2), 130-156. Retrived from http://www.ajournal.co.uk/EFpdfs/EFvolume10(2)/ EFVol.10\%20(2)\%20Article\%206.pdf

Kurtovic, S., Halili, B., \& Maxhuni, N. (2016). Bilateral trade elasticity: B\&H versus its seven trade partners. MPRA Paper No. 72297.

Magee, P. S. (1973). Currency contracts, pass-through, and devaluation. Brookings Papers on Economic Activity, 4(1), 303-325. http://dx.doi. org/10.2307/2534091

Marwah, K., \& Klein, L. R. (1996). Estimation of J-curves: United States and Canada. Canadian Journal of Economics, 29, 523-540. http:// dx.doi.org/10.2307/136248

Nagpal, M. (in press). The J-curve phenomenon: Myth or reality? - An analysis for India. Retrieved from https://www.econ-jobs.com/ research/18594-The-J-curve-Phenomenon--Myth-or-Reality-.pdf

Nguyen, T. H. (2011). Exports, imports, FDI and economic growth. Working Paper No. 11-03, 1-47.

Noland, M. (1989). Japanese trade elasticities and J-curve. The Review of Economics and Statistics, 71(1), 175-179. https://doi. org/10.2307/1928067

Pahlavani, M., Wilson, E., \& Worthington, A. C. (2005). Trade-GDP nexus in Iran: An application of the autoregressive distributed lag (ARDL) model. American Journal of Applied Sciences, 2(7), 1158-1165. http://dx.doi.org/10.3844/ajassp.2005.1158.1165

Pesaran, H. M., Shin, Y., \& Smith, R.J. (1999). Bounds testing approaches to the analysis of long-run relationships. Discussion Paper Series No. 46, 1-42.

Pesaran, M. H., Shin, Y., \& Smith, R. J. (2001). Bounds testing approaches to the analysis of long-run relationships. Journal of Applied Econometrics, 16(3), 289-326. http://dx.doi.org/10.1002/jae.616

Petrović, P., \& Gligorić, M. (2010). Exchange rate and trade balance: J-curve effect. Panoeconomicus, 1, 23-41. http://dx.doi.org/10.2298/ PAN1001023P. Retrieved from http://www.panoeconomicus.rs/casopis/2010_1/02.pdf

Rincón, C. H. (1999). Testing the short-and-long-run exchange rate effects on trade balance: The case of Colombia. Working Paper No. $120,1-41$. Rodrik, D. (2008). The real exchange rate and economic growth. Retrieved from http://online.wsj.com/public/resources/documents/rodrick.pdf Rose, A., \& Yellen, L.J. (1989). Is there a J-curve? Journal of Monetary Economics, 24, 53-68. http://dx.doi.org/10.1016/0304-3932(89)90016-0

Sahlan, R., Abdull, H., \& Boss Abdullah, R. M. (2008). Trade balance and J-curve phenomenon in Malaysia. Journal Ekonomi Malaysia, 42, 91-104. Retrieved from http://www.ukm.my/fep/jem/pdf/2008-42/jeko_42-5.pdf

Siddiqui, S., Zehra, S., Majeed, S., \& Butt, S. M. (2008). Export-led growth hypothesis in Pakistan: A reinvestigation using the bounds test. The Lahore Journal of Economics, 13(2), 59-80. Retrieved from http://www.lahoreschoolofeconomics.edu.pk/JOURNAL/ vol13-no2/4\%20Saima_Sameena_ed_TTC_March_16.pdf

Spitaller, E. (1980). Short-run effects of exchange rate changes on terms of trade and trade balance. IMF Staff Papers, 27, 320-348. http:// dx.doi.org/10.2307/3866715

Stučka, T. (2004). The effects of exchange rate change on the trade balance in Croatia. IMF Working Paper 04/65, 1-21. https://doi. org/10.5089/9781451848717.001

Šimakova, J. (2013). Estimation of the J-curve effect in the bilateral trade of Hungary. Ekonomická revue - Central European Review of Economic, 16, 183-191. Retrieved from https://dspace.vsb.cz/bitstream/handle/10084/101659/simakova-2013-16-3-183.pdf?sequence=1. https://doi.org/10.7327/cerei.2013.09.07

Šimakova, J. (2014). The effects of exchange rate change on the trade balance of Slovakia. European Financial and Accounting Journal, 9(3), 50-56. Retrieved from https://www.vse.cz/efaj/124. https://doi.org/10.18267/j.efaj.124

Šimakova, J., \& Stavarek, D. (2015). The effect of the exchange rate on industry-level trade flows in Czechia. E+M Ekonomie a Management, 8(4), 150-165. http://dx.doi.org/10.15240/tul/001/2015-4-011. Retrieved from http://www.ekonomie-management. cz/download/1449656503_ad1a/11_THE+EFFECT+OF+THE+EXCHANGE+RATE.pdf. https://doi.org/10.15240/tul/001/2015-4-011

Vika, I. (2006). Measuring import and export functions in Albania. Retrieved from https://www.bankofalbania.org/previewdoc. php?crd=5347\&ln=2\&uni=200903191526111901-a

Yuen-Ling, N., \& Wai-Mun, H. (2008). Real exchange rate and trade balance relationship: An empirical study on Malaysia. International Journal of Business and Management, 3(8), 130-137. Retrieved from http://www.ccsenet.org/journal/index.php/ijbm/article/view/1342 


\section{Appendix}

\section{Data sources and description}

It refers to the interpolated (no seasonally adjusted) quarterly data 1994-2015 taken from the following databases:

a) International Financial Statistics of IMF (CD-ROM)

b) Eurostat: Database

c) OECD: data

d) Instat: Bank of Albania

\section{Variables}

$T B_{t}$ : Measures the ratio of trade balance between the domestic country and its trading partners (data were taken from sources b, c).

REER: Real effective exchange rate based on CPI. The real effective exchange rate (REER) on CPI is the weighted average of the Albanian lek relative to an index or basket of other six major currencies, adjusted for the effect of inflation. The weights are determined by comparing the relative trade balance of a country's currency against each country within the index (data were taken from source d).

GDPalb: Real income of Albania. Income of an individual, organization, or country, after taking into consideration the effects of inflation on purchasing power (data were taken from sources b, d).

\section{Authors}

Safet Kurtović received his Ph.D. in economics from the University of Belgrade in 2002. He is a professor at the Faculty of Management and Business Economics, University of Travnik. He started his professional career at the Faculty of Economics in Mostar, the University of Dzemal Bijedic. His research focus is on international economics, international business, international trade, and applied economy.

Blerim Halili received his Ph.D. in economics from the Alfa University in 2009. He is an associate professor at the College "Biznesi," Department of Economics. He research interests include theoretical economics, macroeconomics, and international finance.

Nehat Maxhuni received his Ph.D. in economics from the Alfa University in 2012. He is an associate professor at the College "Biznesi," Department of Economics. He research interests include accounting and finance.

\section{Učinek depreciacije deviznega tečaja na trgovinsko bilanco Albanije}

\section{Izvleček}

Namen članka je raziskati učinek depreciacije realnega efektivnega deviznega tečaja leka na trgovinsko bilanco Albanije z uporabo četrtletnih podatkov med letoma 1994 in 2015. V empirični analizi so bili uporabljeni test meje kointegracije, model vektorske korekcije napak (VECM) in impulzni odziv. Izsledki raziskave kažejo, da obstaja dolgoročna kointegracija med realnim efektivnim deviznim tečajem (REER) in trgovinsko bilanco (TB). Specifično, depreciacija REER ima pozitiven učinek na trgovinsko bilanco Albanije tako dolgoročno kot tudi kratkoročno, kar nakazuje šibek učinek J-krivulje. Iz rezultatov smo izpeljali pomembne zaključke. 